\title{
Seasonal partitioning of resource use and constraints on the growth of soil microbes and a forage grass in a grazed Arctic salt-marsh
}

\section{Sarah K. Hargreaves \& Emma J. Horrigan \& Robert L. Jefferies}

\begin{abstract}
$\underline{\text { Abstract }}$
Seasonal growth responses of plants and soil microorganisms to additions of nitrogen (N), phosphorus (P) and carbon (C) were examined in goose-grazed and exclosed plots in an Arctic salt marsh. Plants showed strong growth responses to N and NP additions but not to P. Nitrogen levels in the shoots and roots of Puccinellia phryganodes declined as summer progressed. Microbial biomass was low in spring in spite of $\mathrm{N}$ and $\mathrm{P}$ additions, likely due to $\mathrm{C}$ limitation, but values rose in autumn, independent of nutrient treatment, as dissolved organic carbon (DOC) increased. Glucose addition ( $C$ source) elicited a transitory increase in microbial biomass. Multiple plant defoliations by geese had a negative effect on microbial biomass, in spite of the presence of DOC and added $\mathrm{N}$ and $\mathrm{P}$, possibly because hypersalinity restricted growth. Plants appear to limit soil inputs of $C$ in summer and compete effectively for resources in contrast to autumn, indicating a temporal partitioning of resources.
\end{abstract}

\section{$\underline{\text { Introduction }}$}

Additions of nitrogen and phosphorus to Arctic soils results in a marked increase in above-ground plant biomass, particularly when applied to graminoid communities indicating that these nutrients are in limited supply (Shaver and Chapin 1980; Chapin and Shaver 1985; Chapin et al. 1986; Jonasson 1992; Press et al. 1998). In contrast, Jonasson et al. (1996) showed that soil microbial biomass failed to increase in response to additions of N, P and potassium, although microbes immobilized large amounts of the nutrients. A recent meta-analysis of different ecosystems indicates an average decline in microbial biomass of 15\%, when N was applied to plots (Treseder 2008). However, when labile C was added to the soil it stimulated microbial biomass suggesting this element was a major limiting nutrient for microbial growth (Jonasson et al. 2006). The presence of plant roots in soil also stimulated microbial growth in response to $\mathrm{C}$ exudates from roots and senescing root tissue, suggesting facilitation rather than competition was occurring between plants and microbes (Jonasson et al. 2006). The carbon compounds released from plant roots include mucilage, exoenzymes, organic acids, sugars and amino acids (Whipps 1990) and these amount to between $5 \%-10 \%$ of the photosynthetic $C$ fixed (Farrar et al. 2003) and provide an important $C$ source for soil microorganisms.

Most of the above studies were conducted during the snow-free season when many plants exhibit a strong growth demand for nutrients particularly in spring and early summer; however, in tussock tundra plant nutrient uptake and root growth occurs in mid-July or later in summer (Weintraub and Schimel 2005a). In contrast, microbes continue to show active growth in the autumn and winter months in alpine and some Arctic soils (Clein and Schimel 1995; Hobbie and Chapin 1996; Brooks et al. 1996, 1998; Grogan and Jonasson 2006; Nobrega and Grogan 2007). Peak annual microbial biomass with slow N turnover rates occurs in late winter (Schimel et al. 2004; Schmidt and Lipson 2004; Edwards et al. 2006; Buckeridge and Jefferies 2007). Nutrients released from cells of senescing microbes when soil 
temperatures rise in late winter and spring may represent the largest single annual input of available $\mathrm{N}$ into these cold soils (Jaeger et al. 1999). Microbial biomass is low in late spring and early summer, most likely because either $\mathrm{N}$ is absorbed by plants for summer growth or that the microorganisms are $\mathrm{C}$ starved (Jaeger et al. 1999; Lipson et al. 1999; Weintraub and Schimel 2005a, b). Although values of microbial biomass remain low throughout much of the summer compared to winter, turnover rates are high (Buckeridge and Jefferies 2007). Although the low values could be the result of foraging by nematodes there was no evidence of the occurrence of high populations ( $>1$ million $\mathrm{m}-2$ ) of nematodes in these soils from late June to late August that might be feeding on microbial biomass in summer; counts were less than $10,000 \mathrm{~m}-2$ in the upper $5 \mathrm{~cm}$ of soil (Jefferies, unpublished data).

Our study was conducted in an intertidal Arctic salt marsh on the Hudson Bay coast dominated by graminoids, where it was previously established that plant growth is $\mathrm{N}$-limited (Cargill and Jefferies 1984). At grubbed sites the $\mathrm{N}$ content of the surface layer of soil is low compared with soils beneath intact swards (McLaren and Jefferies 2004; Buckeridge and Jefferies 2007). In this marsh, rates of net mineralization of soil $\mathrm{N}$ in vegetated plots during the first two-thirds of summer are either very low or are negative (Wilson and Jefferies 1996), similar to results from other studies (Hart and Gunther 1989; Giblin et al. 1991; Jonasson et al. 1993, 2006; Schmidt et al. 1999). Mineralization rates rise in the late summer months (Wilson and Jefferies 1996) but in contrast to the studies described above, graminoid swards have been intensely grazed by herbivores (lesser snow geese, Chen caerulescens caerulescens) during the post-hatch period in summer for at least 40 years (Cooke et al. 1995). High densities of faeces (< 40 m-2 wk-1; Jefferies and Rockwell 2002) result in a rapid increase in above-ground biomass within the season, much of which is consumed by geese (Bazely and Jefferies 1985). In this system, the consumer (geese) is driving plant production following multiple croppings via the direct input of faeces (soluble N), thereby reducing the dependency of plant growth on soil microbial activity. In the absence of faecal input, regrowth of vegetation following defoliation is limited (Bazely and Jefferies 1985; Hik and Jefferies 1990). In addition, where the organic-rich upper-marsh soils are devoid of living roots because of plant removal by geese, microbial biomass and activity are reduced in spite of the absence of competition for $\mathrm{N}$ from plants (Buckeridge and Jefferies 2007). This suggests that labile $\mathrm{C}$ supplied from senescing plant tissue and root exudates contributes to microbial growth (Buckeridge and Jefferies 2007).

A common response to herbivory is a high $\mathrm{N}$ concentration in new shoots following defoliation (Guitian and Bardgett 2000), which was also detected in shoots of the salt-marsh forage grass, Puccinellia phryganodes after snow goose herbivory (Hik and Jefferies 1990). Bardgett et al. (1998) have suggested that an increase in labile $\mathrm{C}$ exudates from the roots of plants subject to defoliation may enhance microbial activity and hence rates of net $\mathrm{N}$ mineralization, thus providing an additional supply of $\mathrm{N}$ for plant regrowth beyond that in faeces. In contrast, other studies have not documented this increase in microbial biomass in response to defoliation (Sørensen et al. 2008). Multiple croppings associated with goose grazing may restrict the flux of root exudates if photosynthetic $\mathrm{C}$ becomes limiting. Although some studies have shown that root exudates appear to facilitate microbial growth and $\mathrm{N}$ mineralization in mid- and late summer (Weintraub and Schimel 2005a, b), in spring and early summer plants and microbes most likely compete for nutrients, especially N (Jaeger et al. 1999; Jonasson et al. 1999; 
Bardgett et al. 2005; Schmidt et al. 2007). In the absence of soluble C exudates from rapidly growing plants in spring, microbes maybe unable to compete effectively for $\mathrm{N}$, as shown by the low amounts of microbial biomass during this period (Jonasson et al. 1999; Bardgett et al. 2005).

We measured changes in soil microbial biomass during the snow-free season in an Arctic intertidal salt marsh, with and without the addition of nutrients, to determine if microbial biomass showed seasonal responses to the presence of actively growing plants and the addition of nutrients that limit plant and microbial growth. We hypothesized that there would be a partitioning of resource use throughout the seasons between plants and microbes that would indicate whether competition for nutrients or facilitation was occurring. In plots that received the addition of $\mathrm{N}$ and $\mathrm{P}$, we predicted that microbes as well as plants would accumulate these elements, although early in the season the absence of $\mathrm{C}$ may limit the growth of microbes and their ability to accumulate $\mathrm{N}$ and $\mathrm{P}$.

In a separate experiment, we examined the effects of snow goose grazing and nutrient additions (C, N, and $\mathrm{P}$ ) on microbial biomass, in order to test how herbivores may influence the availability and uptake of nutrients in this system. We hypothesized based on previous studies, that the increased need for $\mathrm{N}$ by $\mathrm{P}$. phryganodes for regrowth following grazing, would lead plants to exude more labile $\mathrm{C}$ from their roots, stimulating the growth of C-limited microbes. The presence of geese in grazed plots may have indirect effects on both plants and microbes, through the input of faeces, however the final areas sampled within each plots were free of faecal pellets. If soil soluble $\mathrm{C}$ levels limit microbial growth, then plots that received additions of carbon as glucose should show an increase in microbial biomass, independent of grazed and ungrazed treatments. The combined results from these experiments provide an opportunity to assess plant-microbial interactions in a seasonal context, and understand how these relationships are modified by the presence and absence of herbivory.

\section{Materials and methods}

\section{Study site}

The study was conducted at La Perouse Bay on the south-west coast of Hudson Bay in Wapusk National

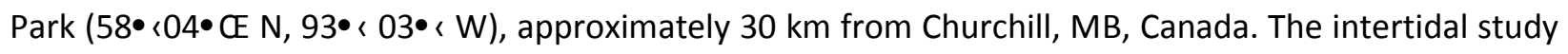
site is inundated with seawater in late summer and autumn during spring tides. The soils are classified as Regosolic Static Cryosols (Agriculture Canada 1987). Much of the salt-marsh vegetation has been lost as a result of goose grubbing, which has exposed the surface organic-rich layer $(<3.0 \mathrm{~cm})$ and the underlying consolidated barren sediments (Jefferies et al. 2002, 2003). Degraded grubbed areas are missing rhizomes and roots of the forage graminoids, most of which occurred in the upper $3 \mathrm{~cm}$ at undistubed sites. The preferred prostrate forage species is an asexual stoloniferous grass, Puccinellia phryganodes, which produces fine white roots annually. Because of grubbing by the geese, only isolated patches of formerly homogeneous grazing lawns (sensu McNaughton 1979) of P. phryganodes remain.

\section{Experimental design and collection of samples in plots}

Experimental plots were established at three sites separated by at least $50 \mathrm{~m}$, on remaining patches (c. 5 $\mathrm{m} \times 5 \mathrm{~m}$ ) of grass swards. On each patch, two wire netting exclosures $(1.25 \mathrm{~m} \times 1.25 \mathrm{~m})$ were erected 
and each plot was divided into a control and three treatment sub-plots, each $50 \mathrm{~cm} \times 50 \mathrm{~cm}$. The total number of samples was six for each treatment and the control, but $n=3$ based on the three sites. Corridors $(10 \mathrm{~cm})$ separated the sub-plots and they were displaced $5 \mathrm{cmfromthe}$ exclosure fence. Salts containing nitrogen and/or phosphorus were added to sub-plots in a fully factorial randomized block design at the beginning of the growing season in 2003 (3 June) and mid-season (10 July). Biomass values in the corridors were similar to those in control plots, indicating no nutrient movement across plots. Amounts of salts were based on those used by Willis (1963) in studies of dune vegetation. Nitrogen was added on each occasion as $\mathrm{NH} 4 \mathrm{Cl}(8.5 \mathrm{~g} \mathrm{~N} \mathrm{~m}-2)$ to nitrogen (N) and nitrogen $x$ phosphorus (NP) subplots. Similarly, phosphorus was added to NP and P sub-plots as salts of Na2HPO4. H2O and Na2HPO4. $2 \mathrm{H} 2 \mathrm{O}$ in equal amounts with respect to $\mathrm{P}$ (total $6 \mathrm{~g} \mathrm{Pm}-2$ on each occasion). The final sub-plot in each exclosure served as the control.

One soil core $(7.2 \mathrm{~cm} \times 6 \mathrm{~cm}$ internal diameter) was collected on six occasions approximately every 2 weeks from early June (day 0) to early August Plant Soil (2009) 322:279-291 2812003 (day 63) from each of the sub-plots inside exclosures at each site $(n=3)$. The cores were used to measure above-ground plant biomass, soil physical and chemical properties, including $\mathrm{pH}$, redox potential, dissolved organic $\mathrm{P}$, exchangeable inorganic $N$, microbial $C, N$ and $P$ and DOC. Four smaller cores $(2.2 \mathrm{~cm}$ diameter $\times 6 \mathrm{~cm}$ depth) were also taken with a cork borer from sub-plots for measurements of root nutrient concentrations, bulk density, and soilextractable orthophosphate using Olsen's extractant (Kuo 1996). Soil cores were stored on the cold ground in deep shade beneath a building and were processed within a day of collection (very occasionally 2 days). In addition to the cores mentioned above that were collected from sub-plots between June and August 2003, cores of a similar size to the large cores were taken from the plots on 25 October 2003 (day 144) in order to measure levels of microbial C, N, and P and soil DOC. As this visit was linked to helicopter availability, there was insufficient time to harvest above-ground plant biomass which in any event had senesced in the partially frozen ground.

A further four sub-plots were established in a third exclosure at each of the three sites, and treated as above, except that in addition each sub-plot received a glucose supplement of $9.6 \mathrm{~g} \mathrm{C} \mathrm{m-2}$ on 27 July 2003. Glucose was selected because of its availability and it is readily taken up and metabolized by microorganisms. Soil cores $(7.2 \mathrm{~cm} \times 6 \mathrm{~cm})$ for estimation of microbial carbon were collected every 2 days from 27 July to 2 August 2003. On 15 June 2006, three pairs of $1 \mathrm{~m} \times 1 \mathrm{~m}$ plots ( $n=3$ ) were set up on remaining patches of $P$. phryganodes, at least $20 \mathrm{~m}$ apart, at the same location as the earlier experiments. One of each pair of plots was exclosed (removing the effects of goose herbivory) and the second plot was left open, which was heavily grazed by adult geese and goslings during the summer. Each plot was further subdivided into four $50 \mathrm{~cm} \times 50 \mathrm{~cm}$ sub-plots, which received one of four nutrient addition treatments: C, NP, NPC, and control (no nutrients added). Amounts of nutrients added to each sub-plot $(50 \mathrm{~cm} \times 50 \mathrm{~cm}$ ) were the same as described above, except for the $C$ addition sub-plots, each of which received $25 \mathrm{~g}$ of glucose (100 g m-2). The experiment was terminated on 3 August 2006 when soil cores similar to those described above were collected for measurement of microbial carbon and aboveand below-ground plant standing crop. 


\section{Processing of plant biomass samples and measurement of soil properties}

Processing of samples took place in the field laboratory at La Pérouse Bay and the Churchill Northern Studies Centre. Frozen late autumn samples were air-freighted (frozen) to the University of Toronto, where they were processed. On each sampling date, the properties of the collected soil cores, including $\mathrm{pH}$, redox potential and bulk density, were measured following established procedures (Srivastava and Jefferies 1995, 1996; Wilson and Jefferies 1996), except experiments involving addition of carbon when only microbial carbon and plant biomass were measured. The above-ground plant biomass from the six intact cores $(n=3)$ taken from similarly treated sub-plots was clipped, rinsed in deionised water, and oven-dried at about $50^{\circ} \mathrm{C}$ for $72 \mathrm{~h}$. All plant biomass was re-dried at $50^{\circ} \mathrm{C}$ for 1 week on arrival in Toronto and weighed to the nearest milligram. Belowground biomass was determined by tweezing live roots from small soil cores $(2.2 \mathrm{~cm}$ diameter $\times 6 \mathrm{~cm})$ and treated as above.

\section{Microbial carbon, nitrogen and phosphorus and soil dissolved organic carbon}

Two sub-samples, each of $70 \mathrm{~g}$ fresh weight were weighed for the estimation of microbial $\mathrm{C}, \mathrm{N}$ and $\mathrm{P}$ using a modified chloroform-fumigation extraction procedure (Witt et al. 2000). One sample was immediately extracted with $140 \mathrm{ml}$ of $0.5 \mathrm{M} \mathrm{K} 2 \mathrm{SO}$, shaken for $1 \mathrm{~h}$ and then filtered using Whatman GF/A filter paper (in the grazing experiment $25 \mathrm{~g}$ of soil were extracted with $50 \mathrm{ml}$ of K2SO4), providing a measure of soil DOC. The second sample was incubated with $2 \mathrm{ml}$ of ethanol-free chloroform for $24 \mathrm{~h}$ in the dark at room temperature. Subsequently, the sample was extracted with $\mathrm{K} 2 \mathrm{SO} 4$ and filtered as described above. Microbial $C$ in the extracts was determined as the difference between unfumigated and fumigated samples using the dichromate titration method to measure carbon (Nelson and Sommers 1996); the values were corrected by a factor of 2.85 ( $\mathrm{kC}=0.35$ for incomplete soil extraction; Jonasson et al. 1996). To estimate microbial $\mathrm{N}$, the total extractable $\mathrm{N}$ in the filtered fumigated and unfumigated soil extracts was oxidised with alkaline persulphate (Cabrera and Beare 1993) and the nitrate produced 282 Plant Soil (2009) 322:279-291 was measured with the use of an auto-analyzer (see below). The difference in $\mathrm{N}$ between oxidised extracts of fumigated and unfumigated soils gave an estimate of microbial $\mathrm{N}$ (corrected by a factor of $2.5, \mathrm{kN}=0.4$ to allow for incomplete extraction; Jonasson et al. 1996). Microbial $P$ was determined as the difference between orthophosphate concentrations between fumigated and non-fumigated samples. After neutralizing the soil extracts, orthophosphate was measured using the molybdate-blue method (Ames 1966) and kP was 0.4 for incomplete extraction (Jonasson et al. 1996).

\section{Extraction of soil inorganic nitrogen and organic phosphate and orthophosphate}

Exchangeable ammonium and nitrate ions and organic phosphate and orthophosphate were extracted from the soil cores collected from each sub-plot on each sampling occasion. Inorganic exchangeable $\mathrm{N}$ was extracted from $15 \mathrm{~g}$ of well-mixed soil using $75 \mathrm{ml}$ of $2 \mathrm{M} \mathrm{KCl}$. Roots and small stones were removed from the sample before weighing. The samples were shaken for $2 \mathrm{~h}$ before they were filtered through preleached $(\mathrm{KCl})$ Whatman No. 1 filter papers. All extracts were frozen and shipped to Toronto for analysis. Orthophosphate was extracted with the use of Olsen's solution (0.5 M NaHCO3 buffered at pH 
8.5 with $1 \mathrm{M} \mathrm{NaOH}$ ), which is widely used as a soil phosphate extractant (Kuo 1996). Two grams of fresh soil were placed in $40 \mathrm{ml}$ of this solution, which was shaken for $1 \mathrm{~h}$ before filtration. Each solution was filtered and the samples frozen. Measurements of organic phosphate were made on filtered (Whatman No. 42) squeezed pore water obtained from the soil samples by hand-squeezing using gloves. The resulting solutions were non-turbid.

\section{Chemical analyses}

Before nutrient analysis, shoots of P. phryganodes were ground to a mesh size of $40 \mathrm{im}$ in a Wiley mill (Thomas Scientific, Swedesboro, N.J., USA). Root tissue for each treatment was pooled on each sampling occasion in order to provide sufficient material for analysis. Amounts of $\mathrm{C}$ and $\mathrm{N}$ in plant tissues were measured with the use of a CHN elemental analyzer (Costech International, Milan, Italy). Following Kjeldahl digestion of plant tissues, $\mathrm{P}$ was measured as orthophosphate in extracts using the molybdateblue method (Ames 1966).

Inorganic $\mathrm{N}$ in soil extracts was measured colorimetrically with the use of an auto-analyzer (Technicon AAll, Tarrytown, NY, USA). Ammonium concentrations were determined using the indophenol blue method (Keeny and Nelson 1982) and nitrate concentrations were measured as nitrite after the extracts were reduced by cadmium and treated with a diazotizing agent (Keeny and Nelson 1982). Orthophosphate was measured in the extracts using the molybdate-blue method (Ames 1966) after neutralisation of the acidity (Grimshaw et al. 1989). Concentrations of soluble organic phosphate were also measured using the molybdate-blue method before and after oxidation of organic $P$ to orthophosphate with acidic potassium persulphate (Lajitha et al. 1999). Dissolved organic phosphorus was calculated as the total dissolved phosphorus in extracts less inorganic phosphorus in extracts.

\section{Statistical treatment of the data}

Before statistical analyses were performed, all data were tested to ensure that they met assumptions of normality (Kolmogorov-Smirnov goodness of fit test) and data were log-transformed when necessary to meet these assumptions. All data sets, except those of root $C$ and $P$ were log-transformed. Although this results in models that are multiplicative rather than additive, only a few interactions were significant.

In order to examine the effect of $\mathrm{N}$ and $\mathrm{P}$ fertilization and $\mathrm{N}, \mathrm{P}$ and $\mathrm{C}$ fertilization over time on plant growth, nutrient content in tissues, and microbial biomass, full factorial repeated measures designs were analyzed using SAS PROC MIXED (SAS Institute Inc. 2004) with N and P (and C) additions and time as fixed effects and site as a random effect. Only significant interactions are modelled; covariance structure (time) was chosen by comparing structures and choosing the one for which the Akaike's Information Criterion is a minimum (Littell et al. 1996). Because two plots per replicate (site) were established, mixed model ANOVAs were also run to test for the effects of nutrient additions in grazed and ungrazed plots to account for within- and between subject design. 


\section{$\underline{\text { Results }}$}

\section{Soil characteristics}

The characteristics of the upper $5 \mathrm{~cm}$ of soil at the study site are typical of salt-marsh soils in the region. Mean values for bulk density were $0.71 \pm 0.006$ SEM g dw cm-3, pH was $7.40 \pm 0.02$ and redox values were $352 \pm 5.0 \mathrm{mV}$. Total $\mathrm{N}$ was $7.90 \pm 0.14 \mathrm{mg} \mathrm{g}-1 \mathrm{dw}$ of soil and total P was $0.64 \pm 0.39 \mathrm{mg}$ g- $1 \mathrm{dw}$ of soil. In spite of two applications of $\mathrm{N}$ to some plots, values of exchangeable $\mathrm{NH} 4+$ and $\mathrm{NO} 3$ - did not differ significantly between treatments. The mean total exchangeable NH4+-N and NO3- $\mathrm{N}$ values for all plots were $1.59 \pm 0.18 \mathrm{mg}$ and $1.11 \pm 0.13 \mathrm{mg}$ g- $1 \mathrm{dw}$ of soil respectively. There was a seasonal decline in exchangeable ammonium ions ( $F 2,20=7.1, P=0.0046)$ in the different sub-plots, even though $\mathrm{N}$ was added to two treatments (N, NP) on day 37. The results of Olsen's extractable phosphate indicated that levels of extractable $\mathrm{P}$ were very low and showed no trend in relation to either season or treatment. Amounts of soluble organic $P$ were also very low in all treatments throughout the summer and early autumn and no seasonal trends were evident ( $F 4,47=1.4, P=0.246)$.
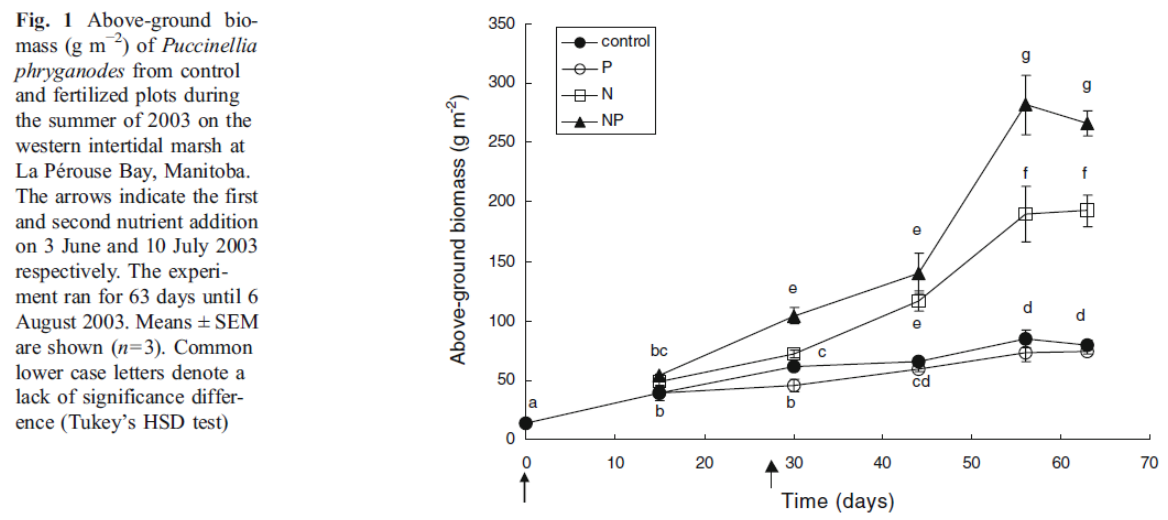

\section{Plant responses to fertilization}

Results of the fertilization experiment in which the main effects ( $\mathrm{N}$ and $\mathrm{P}$ ) on above-ground biomass are plotted (Fig. 1) showed that the growth curve is sigmoid in the NP and N plots and the increase in biomass is co-limited by both $\mathrm{N}$ and $\mathrm{P}$ following addition of $\mathrm{N}$ (i.e. there is synergy in the NP treatment; c.f. Elser et al. 2007). Overall values of above-ground biomass in control and $P$ sub-plots remained statistically similar throughout the experiment $(\mathrm{F} 4,98=1.1, \mathrm{P}=0.352)$ resulting in a linear increase in weight over time. Above-ground biomass in the nitrogen-alone sub-plots responded with a significant increase in production beyond that of the control subplots $(F 1,98=318, P<0.0001)$ reaching a maximum at the final harvest, whereas the mean biomass in the NP sub-plots was $266 \pm 11 \mathrm{~g} \mathrm{~m}-2$ compared with that for the control sub-plots of $79 \pm 2 \mathrm{~g} \mathrm{~m}-2(\mathrm{~F} 1,98=26.0, \mathrm{P}<0.0001)$ on that date (day 63$)$ and NP was significantly higher than $\mathrm{N}$ addition alone.

The carbon concentration of all shoot tissues (\% dry weight) was about $44.5 \%$ for the duration of the experiment (data not shown). In contrast, the $\mathrm{N}$ concentration in shoots (Fig. 2 a) showed a significant and positive response to $N$ additions in the $N$ and NP sub-plots ( $F 1,102=542, P<0.0001)$. There was also a significant seasonal change in shoot $\mathrm{N}$ accumulation (F5, 102=93, $\mathrm{P}<0.0001)$, as well as a significant $\mathrm{N}$ 
by time interaction ( $F 4,102=7.7, \mathrm{P}<0.0001)$. Concentrations of shoot $\mathrm{N}$ increased and then decreased following each of the two nutrient additions on 3 June and 10 July 2003. Average shoot concentration of phosphorus was generally higher in the NP sub-plots than in the $P$ sub-plots $(F 1,99=18.2, P<0.0001$ ) (Figs. 2 b). Although there was a significant effect of time (F5, 99=18.6, $\mathrm{P}<0.0001)$ and $\mathrm{N}$ fertilization (F1, $99=7.7, P=0.007$ ), shoot $P$ remained relatively constant throughout the growing season (Fig. 2 b). Shoot $\mathrm{P}$ concentration in P-fertilized sub-plots was significantly higher than the mean $\mathrm{P}$ shoot concentration in sub-plots which did not receive $P(F 1,99=309, P<0.0001)$.

The $C$ allocation to the roots from the different subplots changed significantly over time (F4, 38=20.6, $\mathrm{P}<0.0001$ ) (data not shown). Values ranged from $35 \%$ of the dry weight after 15 days to $42 \%$ in late July but declined in August. The seasonal rise and decline were more evident in N-enriched plots ( $F 1,38=5.7$, $\mathrm{P}=0.023$ ). The average $\mathrm{N}$ concentration in roots (Fig. $2 \mathrm{c}$ ) from the control and $\mathrm{P}$ sub-plots dropped in mid-summer $(F 4,37=35.3, P<0.0001)$ and remained low, whereas the $\mathrm{N}$ concentration in roots was highest in the $N$ and NP treatments ( $N$-effect: $F 1,37=159, P<0.0001$ ). Significantly more $P$ was allocated to roots in $P$ and NP sub-plots ( $F 1,28=95, P<0.0001)$ (Fig. 2 d). In sub-plots that received no $P$ amendments, the $P$ concentration did not change during the summer ( $F 4,28=2.4, P=0.073)$ (Fig. $2 \mathrm{~d}$ ).

The total $\mathrm{N}$ and $\mathrm{P}$ contents of the accumulated biomass indicate that together the shoots and roots of $\mathrm{P}$. phryganodes contained an equivalent in the range of $38 \%$ to $61 \%$ of the total $\mathrm{N}$ applied to the $\mathrm{N}$ and NP sub-plots. The lower percentages were associated with plants growing in sub-plots to which only $\mathrm{N}$ was added. In contrast, the corresponding percentages in the cumulative biomass for $\mathrm{P}$ in sub-plots receiving this element were less than $15 \%$ of the amount added and most were below $10 \%$.
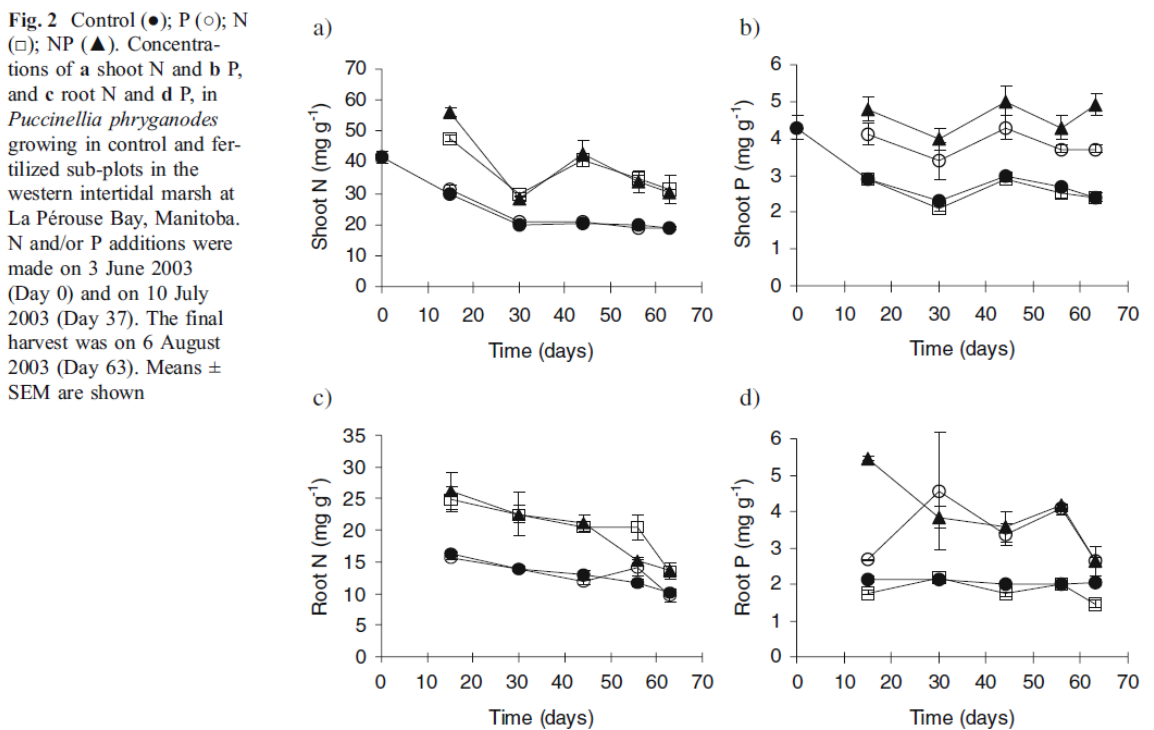

\section{Microbial $\mathrm{C}, \mathrm{N}$ and $\mathrm{P}$ in response to soil fertilization}

Soil microbial carbon varied over time $(F 5,39=18.8, P<0.0001)$, as values increased in all sub-plots throughout the summer and autumn to over ten times the initial mean value of $0.19 \mathrm{mg} \mathrm{C} \mathrm{g.1dw} \mathrm{of} \mathrm{soil}$ on 3 June (Fig. 3 a) by October, 2003. This rise was associated with an increase in DOC over the same period, but only in October (Fig. 3 d) (F5, 40=17.9, P<0.0001). The Tukey-Kramer tests indicated that 
DOC and microbial $C$ in October was significantly higher than on all other sampling dates $(P<0.0001)$. Soil microbial N (Fig. 3 b) also increased in all sub-plots six-fold or more during the same period (F5, 38=5.6, $\mathrm{P}=0.0006$ ) from an overall mean of about $43.5 \mathrm{ig} \mathrm{N} \mathrm{g.1} \mathrm{dry} \mathrm{wt} \mathrm{of} \mathrm{soil} \mathrm{to} \mathrm{between} 200$ and $300 \mathrm{ig} \mathrm{N} \mathrm{g.1dw}$ of soil. Soil microbial $P$ ranged from a mean of 1.89 to over 8 ig P g.1 dw of soil by late October (F5, $39=0.65, P=0.667$ ), but there was no overall increase in microbial $P$ in autumn (Fig. $3 \mathrm{c}$ ). There was no significant response of microbial $\mathrm{C}, \mathrm{N}$, or $\mathrm{P}$ to the additions of $\mathrm{N}, \mathrm{P}$ and NP; values were similar to those from control plots. The sediments beneath intact swards do not show extreme temperature shifts, differences in $\mathrm{pH}$, or strong seasonal trends in soil moisture content (Srivastava and Jefferies 1995, 1996; Wilson and Jefferies 1996; McLaren and Jefferies 2004).

The response to the addition of glucose to plots on 27 July 2003 was rapid. Only microbial carbon showed an overall significant change during the six-day period, there were no significant changes in the $\mathrm{N}$ and $\mathrm{P}$ concentrations in microbial biomass, even in plots that received additions of these nutrients ( $\mathrm{C}$ : F3, 27=3.3, P=0.035; N: F3, 30=0.26, P=0.856; P: F3, 30=0.03, P=0.994) (Fig. 4). Carbon increased to maximum values between days 2 and 4 and dropped back to the initial value by day 6 . In the grazing experiment conducted in 2006, soil microbial C was significantly higher in ungrazed plots (Fig. 5 a), $(F=7.86, P=0.012)$ but the effects of $C, N$ and $P$ additions on microbial $C$ again were not significant within the grazing treatment (NP: $F=0.13, P=0.720 ; C: F=0.41, P=0.529$ ). In this experiment, microbial $C$ was measured almost 2 months after the addition of glucose to plots because visits were dependent on helicopter availability. DOC was significantly higher in soils from grazed plots (Fig. $5 \mathrm{~b}),(\mathrm{F}=12.16$, $\mathrm{P}=0.002$ ), although again there were no nutrient addition effects on DOC (NP: $F=1.21, P=0.283$; $C$ : $\mathrm{F}=2.74, \mathrm{P}=0.114)$. The mean aboveground standing crop $(15.7 \pm 1.3 \mathrm{~g} \mathrm{~m}-2$ in control plots; $21.7 \pm 3.0 \mathrm{~g} \mathrm{~m}-2$ in NP-treated plots) of P. phryganodes was not significantly different between grazed plots receiving the different nutrient additions ( $F 3,8=1.62, \mathrm{P}=0.261)$, whereas in exclosed plots mean values of standing crop ranged from $108.0 \pm 6.3 \mathrm{~g} \mathrm{~m}-2$ in control plots to $227.0 \pm 33.6 \mathrm{~g} \mathrm{~m}-2$ in the NPC treatment $(F 3,8=12.2$, $\mathrm{P}=0.002$ ).

\footnotetext{
Fig. 3 Control (•); P (o); N $(\square)$; NP $(\boldsymbol{\Delta})$. Soil microbial a carbon, b nitrogen, $c$ phosphorus, and d dissolved organic carbon per gram dry weight of soil in control and fertilized subplots in the western intertidal marsh at La Pérouse Bay, Manitoba during the summer of 2003 Nutrient additions were made on days 0 and 37 ( 3 June and 10 July 2003). Soil was collected at rooting depth $(5 \mathrm{~cm})$. Means \pm SEM are shown $(\mathrm{n}=3)$. The final harvest was on 25 October 2003 (144 days). Soil microbial $\mathrm{C}$ and $\mathrm{N}$ were corrected using extractability factors $\mathrm{k}_{\mathrm{EC}}=0.35$ and $\mathrm{k}_{\mathrm{EN}}=0.40$, respectively; soil microbial $\mathrm{P}$ was corrected using the factor $\mathrm{k}_{\mathrm{fix}}=0.77$
}
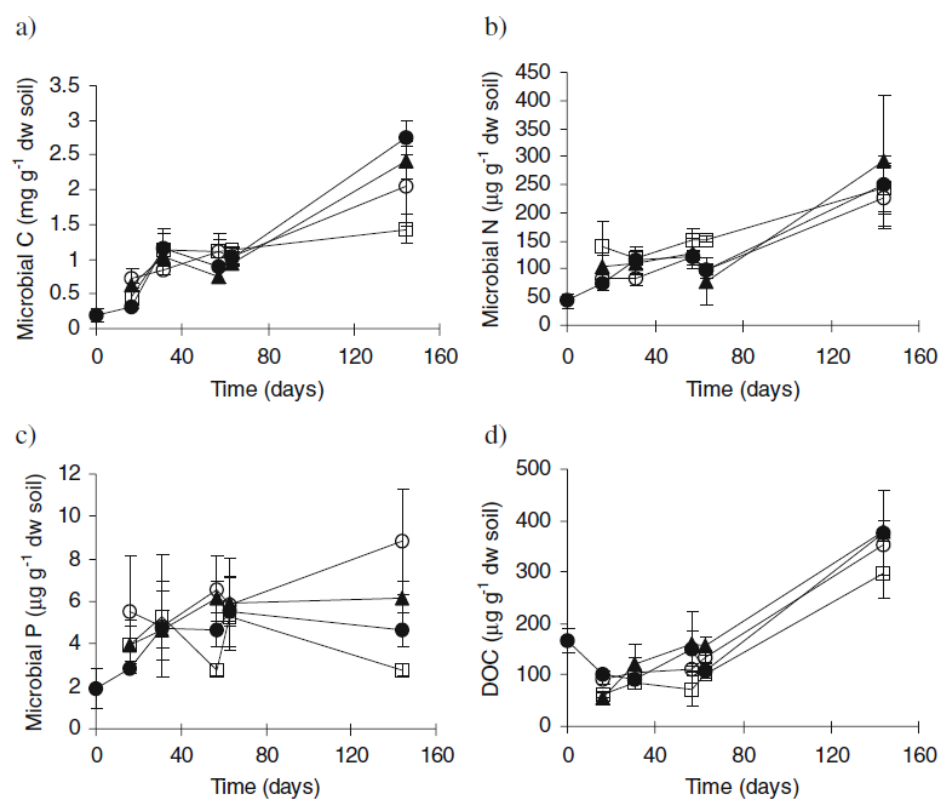


\section{Discussion}

Remaining patches of P. phryganodes located along the intertidal flats at La Pérouse Bay showed a strong growth response within the season to exogenous $\mathrm{N}$ and $\mathrm{P}$ inputs, similar to previous studies (Fig.1) (Cargill and Jefferies, 1984; Ngai and Jefferies 2004). However, the time courses of the concentrations of $\mathrm{N}$ and $\mathrm{P}$ in plants subject to the different treatments do not show similar trends (Fig. 2). The decline in $\mathrm{N}$ concentrations in shoots and roots of plants from $\mathrm{N}$-treated plots (Fig. $2 \mathrm{a}, \mathrm{c}$ ) is likely the result of growth dilution associated with the increase in biomass, similar to the studies of Chapin et al. (1986). This does not imply $\mathrm{N}$ is no longer absorbed just that the growth rate slows in late summer at which time much of the biomass is structural carbohydrate. The $\mathrm{N}$ concentration in tissues from untreated plots declined rapidly as growth proceeded and the results indicate that pools of $\mathrm{N}$ and possibly $\mathrm{P}$ in unamended soils are rapidly depleted after growth commences in late spring. This interpretation is consistent with the results of Henry and Jefferies $(2002,2003)$ who showed that exchangeable NH4 and NO3 ions fell to very low levels at the beginning of the growing season and that P. phryganodes utilized organic $\mathrm{N}$ rather than inorganic $\mathrm{N}$, as shown in earlier studies of other Arctic and alpine species (Kielland 1994; Raab et al. 1996; Schimel and Chapin 1996; Lipson and Monson 1998).Wilson and Jefferies (1996) also showed that in this salt marsh, net $\mathrm{N}$ mineralization rates were either very low or negative in early and mid-summer, a finding similar to the studies of Hart and Gunther (1989), Giblin et al. (1991), Jonasson et al. (1993, 1996) and Schmidt et al. (2007). Although these estimates are based on the use of the buried bag technique which may underestimate net $\mathrm{N}$ mineralization rates, as senescing roots and root hairs, which provide a source of $\mathrm{N}$, are not included (Jonasson et al. 2004). The overall growth responses of P. phryganodes and the net accumulation of $\mathrm{N}$ and $\mathrm{P}$ during the summer (Figs. 1 and 2) are similar to the responses of Arctic and alpine species studied by Jaeger et al. (1999) and Jonasson et al. (1999) to additions of nutrients. Soil microorganisms do not appear to be able to compete effectively for $\mathrm{N}$ early in the season, possibly because of the low amount of microbial biomass following the late winter decline due to the lack of labile carbon (Schimel and Clein 1996; Jaeger et al. 1999; Bardgett et al. 2005; Edwards et al. 2006).

The pattern of microbial $\mathrm{C}, \mathrm{N}$, and $\mathrm{P}$ in the snow-free season stands in sharp contrast to the corresponding pattern of the concentrations of these elements in plant tissues (Fig. 3). Firstly, there are very few differences between treatments for each element on the different sampling dates, similar to the results of Jonasson et al. (1996) and those of the meta-analysis of Treseder (2008). Values of microbial C, N and P in control plots are comparable with those from N- and P-treated plots (Fig. 3). Secondly, the values rose late in the experimental period, so that the highest values occurred in early August and late October (Fig. 3). We suggest that microbial growth is primarily limited by $\mathrm{C}$ and that until the spring flush of plant growth is complete and new roots are established, little labile $\mathrm{C}$ is available either as root exudates or from senescing tissues (Fig. $3 \mathrm{~d}$ ). From July onwards, it is likely that the availability of labile $\mathrm{C}$ comes from root activity and the decomposition of plant tissue, and sustains a modest increase in microbial biomass, but there still appears to be inadequate amounts to elicit different microbial growth responses between treatments (Fig. 3). Microbial C and DOC peaked in late October, particularly in plots where $\mathrm{N}$ additions were made (Fig. 3 a,d). Labile $\mathrm{C}$ released from senescing 
plant tissue is thought to allow microorganisms to flourish in the absence of plant competition for about a month before complete freezeup (Jaeger et al. 1999; Bardgett et al. 2005).

Results from the glucose addition experiment also provide evidence in support of microbial $\mathrm{C}$ limitation (Fig. 4). Plots that received low levels of glucose addition (9.6 g m-2), showed a rapid transitory increase in microbial $C$ that lasted 6 days before values returned to the initial levels. In a recent study, Boddy et al. (2008) showed that in Arctic tundra soils, the half-time for the utilization of $14 \mathrm{C}$ glucose and amino acids by microorganisms was less than $2 \mathrm{~h}$. In the grazing experiment of 2006, the short-term microbial response (days) to $\mathrm{C}$ addition had long passed when samples were taken in August (c.f. Sørensen et al. 2008). The results indicated that after nearly 2 months soil microbial $C$ was lower in grazed plots compared with ungrazed plots (Fig. 5 a) with no significant effects of NP addition on soil microbial C. Plant regrowth following multiple croppings creates a $C$ sink and it is unlikely that much $C$ is released from roots compared with ungrazed plants. These results support previous findings from this salt marsh that show microbial biomass is strongly dependent on intact swards of $P$. phryganodes, which directly and indirectly modulate soil nutrient supply (Buckeridge and Jefferies 2007). Despite lower microbial C in grazed compared to ungrazed plots, DOC values were still two-thirds of values in soils from heavily grazed plots (Fig. 5 b), suggesting that adequate DOC concentrations were present to meet microbial C demand in late summer. It may be that microbes cannot readily utilize the soluble organic compounds produced by plants (e.g. secondary chemical compounds). A second and more likely reason is that in plots where plants were heavily grazed down to the pseudostem $(0.5 \mathrm{~cm}$ in height) the exposed sediment was hypersaline, with salinity in excess of $50 \mathrm{~g}$ litre-1 of solutes (Srivastava and Jefferies 1995, 1996; McLaren and Jefferies 2004), which restricted microbial growth. In these plots (standing crop 10$22 \mathrm{~g} \mathrm{~m}-2$ ), the hypersaline exposed soil may have restricted microbial growth leading to an accumulation of DOC (tides flood the mid- and upper marsh in August). In contrast, the soil salinity below ungrazed plots (standing crop, 80-220 g m-2) is hyposaline in summer (Srivastava and Jefferies 1995, 1996; McLaren and Jefferies 2004). Both urease activity and nitrification are reduced when these soils are hypersaline, which is consistent with a decline in microbial activity (Wilson et al. 1999). It is well known that soil evaporation and surface salt deposition in the nontidal upper levels of salt marshes in temperate and tropical regions in summer result in hypersaline sediments (see Adam 1990 for a list of references). However, we are unaware of other sites where hypersalinity is caused by overgrazing.

Microbial C, N and P are unlikely to rise until autumn when plant demand for nutrients drops, tissues senesce and salinity decreases. The die-back of plant tissue and the absence of plant competition results in sufficient resources to sustain a large increase in microbial biomass (c.f. Weintraub and Schimel 2005a; Bardgett et al. 2005; Cardon and Gage 2006; Chapman et al. 2006; Schmidt et al. 2007). Hence, nutrient-poor hypersaline soils, multiple cropping events and a nutrient supply for regrowth, largely uncoupled from soil processes, severely constrain microbial growth during much of the snow-free season. In short, the consumer and the forage plant appear to modulate microbial growth during the snow-free season, and soil interactions involve competition in spring and early summer, and limited facilitation in late summer and early autumn, when swards are no longer actively growing and the geese have migrated. 


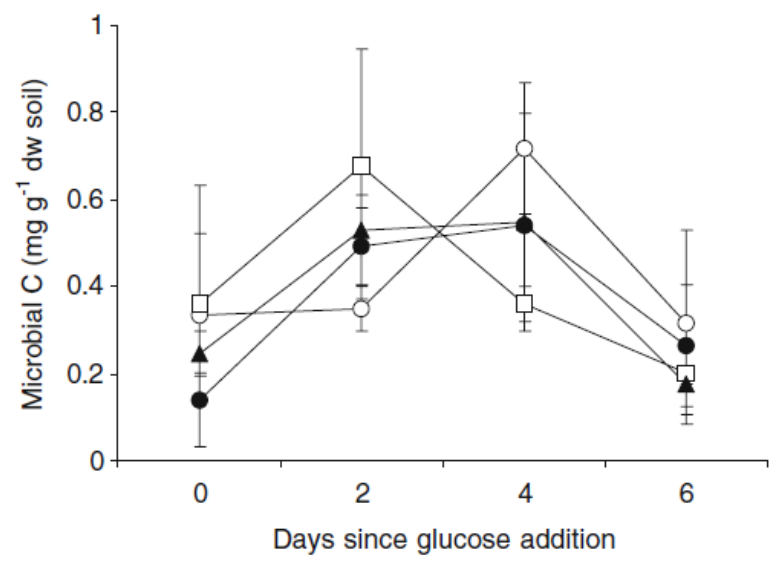

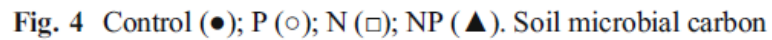
per gram dry weight of soil in N, P, and NP and control plots to which $\mathrm{C}$ was added at day 0 on 27 July 2003. Soil was collected at rooting depth $(5 \mathrm{~cm})$. Means \pm SEM are shown $(n=3)$. Microbial C was corrected using extractability factor $\mathrm{k}_{\mathrm{EC}}=0.35$
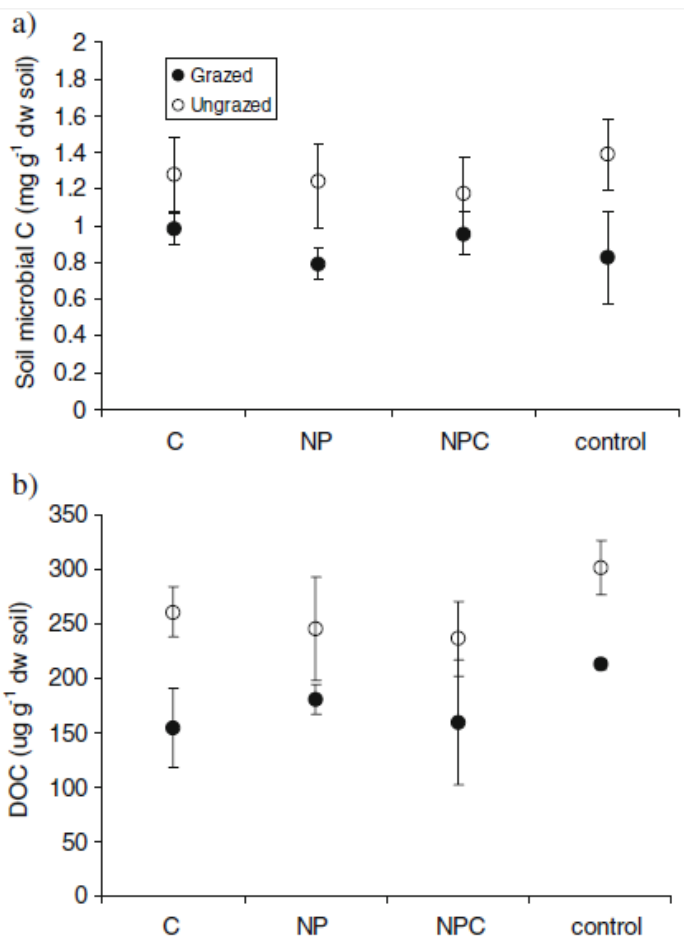

Fig. 5 a Soil microbial carbon and $\mathbf{b}$ dissolved organic carbon on grazed and ungrazed C, NP, and CNP-fertilized plots. Nutrients were added on 15 June 2006 and plants and soil were harvested on 3 August 2006. Soil was collected at rooting depth $(5 \mathrm{~cm})$. Means \pm SEM are shown $(n=3)$. Microbial $\mathrm{C}$ was corrected using extractability factor $\mathrm{k}_{\mathrm{EC}}=0.35$

This temporal pattern of resource use by microbes and plants is consistent with previous findings from other systems. Over a decade ago Jonasson et al. (1996) indicated that in Arctic/alpine heaths and fellfields, the application of $\mathrm{N}, \mathrm{P}$ and $\mathrm{K}$ did not affect the microbial $\mathrm{C}$, in contrast to sugar amendments. In a related study, in the same salt marsh at La Pérouse Bay, low microbial biomass values during the summer was accompanied by a rapid turnover of microbial $\mathrm{N}$, while high biomass values in late winter and early spring showed low turnover rates (Buckeridge and Jefferies 2007). The study by Jaeger et al. (1999) in an alpine meadow also provides strong evidence of temporal partitioning of nutrients between plants and soil microbes. The dominant sedge in this community took up the most $\mathrm{N}$ after snow melt as the microbial biomass declined, until autumn, at which time soil microbes immobilized $\mathrm{N}$ following plant senescence. Soil microorganisms appear dependent on the quality of labile plant $\mathrm{C}$ compounds to control rates of $\mathrm{N}$ mineralization in summer; the greater the input of high quality $\mathrm{C}$ compounds, the greater the rate at which soil microbes immobilize and release $N$ (Knopps et al. 2002). However, lack of labile plant $\mathrm{C}$ in the soil creates a $\mathrm{C}$ bottleneck for microbial growth and $\mathrm{N}$ mineralization via a negative feedback. How widespread this is in different plant communities is unknown. Multicropping events may exacerbate the shortage of labile soil $C$ as plant photosynthetic $C$ is allocated to regrowth and in this marsh at least high salinities likely further curtail microbial growth in summer. 


\section{$\underline{\text { Acknowledgements }}$}

We thank Kate Edwards, Emma Peacocke and Deborah Tam for excellent field and laboratory assistance and Paul Grogan and Hugh Henry for their constructive criticism of an earlier draft. We particularly thank the referees for their valuable comments and helpful suggestions. The research was funded by NSERC and IPYgrants to R.L.J. and E.H; S.H. and E.H. also received a Northern Student Supplement from the Department of Indian Affairs and NorthernDevelopment. The following agencies kindly provided logistic support: Hudson Bay Project, Parks Canada, Churchill Northern Studies Centre and Hudson Bay Helicopters. 


\section{References}

Adam P (1990) Salt marsh ecology. Cambridge University Press, Cambridge, U.K

Agriculture Canada Expert Committee on Soil Survey (1987) The Canadian System of Soil Classification, 2nd edn. Agriculture Canada Publication 1646, Ottawa, Canada

Ames B (1966) Assay of inorganic phosphate, total phosphate and phosphatases. In: Neufeld EF, Ginsburg V (eds) Methods in Enzymology, Complex Carbohydrates. vol. 8. Academic Press, New York, pp 115-118

Bardgett RD, Wardle DA, Yeates GW (1998) Linking aboveground and below-ground interactions: How plant responses to foliar hebivory influence soil organisms. Soil Biol. and Biochem. 30:1867-1878

Bardgett RD, Bowman WD, Kaufmann R, Schmidt SK (2005) A temporal approach to linking aboveground and belowground ecology. Trends Ecol Evol 20:634-641

Bazely DR, Jefferies RL (1985) Goose faeces: a source of nitrogen for plant growth in a grazed salt marsh. J Appl Ecol 22:693-703

Boddy E, Roberts P, Hill PW, Farrar J, Jones DL (2008) Turnover of low molecular weight dissolved organic C (DOC) and microbial C exhibit different temperature sensitivities in Arctic tundra soils. Soil Biol Biochem 40:1557-1566

Brooks PD, Williams MW, Schmidt SK (1996) Microbial activity under alpine snowpacks, Niwot Ridge, Colorado. Biogeochem. 32:93-113

Brooks PD, Williams MW, Schmidt SK (1998) Inorganic nitrogen and microbial biomass dynamics before and during spring snowmelt. Biogeochem. 43:1-15

Buckeridge KM, Jefferies RL (2007) Vegetation loss alters soil nitrogen dynamics in anArctic salt marsh. J Ecol 95:283-293

Cabrera ML, Beare MH (1993) Alkaline persulfate oxidation for determining total nitrogen in microbial biomass extracts. Soil Sci Soc Am J 57:1007-1012

Cardon ZG, Gage DJ (2006) Resource exchange in the rhizosphere: molecular tools and the microbial perspective. Annu Rev Ecol Evol Syst 37:459-488

Cargill SM, Jefferies RL (1984) Nutrient limitation of primary productivity in a sub-arctic salt marsh. J Appl Ecol 21:657-686

Chapin FS III, Shaver GR (1985) Individualistic growth response of tundra plant species to environmental manipulations in the field. Ecology 66:564-576

Chapin FS III, Vitousek PM, Van Cleve K (1986) The nature of nutrient limitation in plant communities. Am Nat 127:48-58 
Chapman SK, Langley JA, Hart SC, Kock GW (2006) Plants actively control nitrogen cycling : uncorking the microbial bottleneck. New Phytol 169:27-34

Clein JS, Schimel JP (1995) Microbial activity of tundra and taiga soils at sub-zero temperatures. Soil Biol Biochem 19:49-59

Cooke F, Rockwell RF, Lank DB (1995) The Snow Geese of La Pérouse Bay. Oxford University Press, Oxford

Edwards KA, McCulloch J, Kershaw GP, Jefferies RL (2006) Soil microbial and nutrient dynamics in a wet Arctic sedge meadow in late winter and early spring. Soil Biol Biochem 38:2843-2851

Elser JJ, Braken MES, Cleland EE, Gruner DS, Harpole WS, Hillebrand H, Ngai JT, Seabloom EW, Shurin JB, Smith JE (2007) Global analysis of nitrogen and phosphorus limitation of primary producers in freshwater, marine and terrestrial ecosystems. Ecol Lett 10:1135-1142

Farrar J, Hawes M, Jones D, Lindow S (2003) How roots control the flux of carbon to the rhizosphere. Ecology 84:827-837

Giblin AE, Nadelhoffer KJ, Shaver GR, Laundre JA, McKerrow AJ (1991) Biogeochemical diversity along a riverside toposequence in arctic Alaska. Ecol Monogr 61:415-435

Grimshaw HM, Allen SE, Parkinson JA (1989) Nutrient elements. In: Allen SE (ed) Chemical analysis of ecological materials. Blackwell Scientific Publications, Oxford, pp 81-159

Grogan P, Jonasson S (2006) Ecosystem CO2 production during winter in a Swedish subarctic region: the relative importance of climate and vegetation type. Glob Chang Biol 12:1479-1495

Guitian R, Bardgett RD (2000) Plant and soil microbial responses to defoliation in temperate emi-natural grassland. Plant Soil 220:271-277

Hart SC, Gunther AJ (1989) In situ estimates of annual nitrogen mineralization and nitrification in a subarctic watershed. Oecologia 80:284-288

Henry HAL, Jefferies RL (2002) Free amino acid, ammonium and nitrate concentrations in soil solutions of a grazed coastal marsh in relation to plant growth. PI Cell Envir 25:665-675

Henry HAL, Jefferies RL (2003) Plant amino acid uptake, soluble $\mathrm{N}$ turnover and microbial $\mathrm{N}$ capture in soils of a grazed Arctic salt marsh. J Ecol 91:627-636

Hik DS, Jefferies RL (1990) Increases in the net above-ground primary production of a salt-marsh forage grass: a test of the predictions of the herbivore-optimization model. J Ecol 78:180-195

Hobbie SE, Chapin FS III (1996) Winter regulation of tundra litter carbon and nitrogen dynamics. Biogeochemistry 35:327-338 
Jaeger CH III, Monson RK, Fisk MC, Schmidt SK (1999) Seasonal partitioning of nitrogen by plants and soil microorganisms in an alpine ecosystem. Ecology 80:1883-1891

Jefferies RL, Rockwell RF (2002) Foraging geese, vegetation loss and soil degradation in an Arctic salt marsh. Appl Veg Sci 5:7-16

Jefferies RL, Rockwell RF, Abraham KF (2003) The embarrassment of riches: agricultural food subsidies, high goose numbers and a loss of Arctic wetlands-a continuing saga. Env Rev 44:193-232

Jonasson S (1992) Plant responses to fertilization and species removal in tundra related to community structure and clonality. Oikos 63:420-429

Jonasson S, Havström M, Jensen M, Callaghan TV (1993) In situ mineralization of nitrogen and phosphorus in arctic soils after perturbations simulating climate change. Oecologia 95:179-186

Jonasson S, Michelsen A, Schmidt IK, Nielsen EV, Callaghan TV (1996) Microbial biomass C, N and P in two arctic soils and responses to addition of NPK fertilizer and sugar: Implications for plant nutrient uptake. Oecologia 106:507-515

Jonasson S, Michelsen A, Schmidt IK, Nielsen E (1999) Responses in microbes and plants to changed temperature, nutrient and light regimes in the Arctic. Ecology 80:1828-1843

Jonasson S, Castro J, Michelsen A (2004) Litter, warming and plants affect respiration and allocation of soil microbial and plant $C, N$, and $P$ in arctic mesocosms. Soil Biol Biochem 36:1129-1139

Jonasson S, Castro J, Michelsen A (2006) Interactions between plants, litter and microbes in cycling of nitrogen and phosphorus in the arctic. Soil Biol Biochem 38:526-532

Keeny DR, Nelson DW(1982) Nitrogen: inorganic forms. In: Page AL (ed) Methods of Soil Analysis Part 2. Soil Science Society of America, Madison, Wisconsin, USA, pp 643-698

Kielland K (1994) Amino acid absorption by arctic plants: Implications for plant nutrition and nitrogen cycling. Ecology 75:2373-2383

Knopps JMH, Bradley KI, Wedin DA (2002) Mechanisms of plant species impacts on ecosystem nitrogen cycling. Ecol Lett 5:454-466

Kuo S (1996) Phosphorus. In: Sparks DL, Page AL, Helmke PA, Loeppert RH, Solanpour PN, Tabatabai MA, Johnston CT, Sumner ME (eds) Methods of Soil Analysis, Part 3: Chemical Methods. Soil Science Society of America, Madison, Wisconsin, USA, pp 869-919

Lajitha K, Driscoll CT, Jarrell WM, Elliot ET (1999) Soil phosphorus: characterization and total element analysis. In: Robertson GP, Coleman DC, Bledsoe CS, Sollins P (eds) Standard Soil Methods for Long-Term Ecological Research. Oxford University Press, Oxford, pp 115-142

Littell RC, Milliken GA, Stroup WW, Wolfinger RD (1996) SAS system for mixed models. SAS Publishing, Cary, North Carolina, USA 
Lipson DA, Monson RK (1998) Plant-microbe competition for soil amino acids in the alpine tundra: effects of freezethaw and dry-rewet events. Oecologia 113:406-414

Lipson DA, Schmidt SK, Monson RK (1999) Links between microbial population dynamics and nitrogen availability in an alpine ecosystem. Ecology 80:1623-1631

McLaren JR, Jefferies RL (2004) Initiation and maintenance of vegetation mosiacs in an Arctic salt marsh. J Ecol 92:648- 660

McNaughton SJ (1979) Grazing as an optimization process: grass-ungulate relationships in the Serengeti. Am Nat 113:691-703

Nelson DW, Sommers LE (1996) Total carbon, organic carbon, and organic matter. In: Sparks DL, Page AL, Helmke PA, Loeppert RH, Solanpour PN, Tabatabai MA, Johnston CT, Summer ME (eds) Methods in Soil Analysis, Part 3: Chemical Methods. Soil Science Society of America, Madison, Wisconsin, pp 9611010

Ngai JT, Jefferies RL (2004) Nutrient limitation of plant growth and forage quality in Arctic coastal marshes. J Ecol 92:1001-1010

Nobrega S, Grogan P (2007) Deeper snow enhances winter respiration from both plant-associated and bulk soil carbon pools in birch hummock tundra. Ecosystems 10:315-327

Press MC, Potter JA, Burke MJW, Callagan TV, Lee JA (1998) Responses of a subarctic shrub heath community to simulated environmental change. J Ecol 86:315-337

Raab TK, Lipson DA, Monson RK (1996) Non-mycorrhizal uptake of amino acids by roots of the alpine sedge Kobresia myosurioides: implications for the alpine nitrogen cycle. Oecologia 108:488-494

SAS Institute Inc. (2004) SAS/STAT User's Guide, Version 9. SAS Institute Inc., Cary, North Carolina, USA

Schimel JP, Chapin FS III (1996) Tundra plant uptake of amino acid and NH4 + nitrogen in situ: plants compete well for amino acid N. Ecology 77:2142-2147

Schimel JP, Clein JS (1996) Microbial response to freeze-thaw cycles in tundra and taiga soils. Soil Biol Biochem 28:1061-1066

Schimel JP, Bilbrough C, Welker JA (2004) Increased snow depth affects microbial activity and nitrogen mineralization in two Arctic tundra communities. Soil Biol Biochem 36:217-227

Schmidt IK, Jonasson S, Michelsen A (1999) Mineralization and microbial immobilization of N and P in arctic soils in relation to season, temperature and nutrient amendment. Appl Soil Ecol 11:147-160

Schmidt SK, Lipson DA (2004) Microbial growth under the snow: Implications for nutrient and allelochemical availability in temperate soils. Plant Soil 259:1-7 
Schmidt SK, Costello EK, Nemergut DR, Cleveland CC, Reed SC, Weintraub MN, Meyer AF, Martin AM (2007) Biogeochemical consequences of rapid microbial turnover and seasonal succession in soil. Ecology 88:1379-1385

Shaver GR, Chapin FS III (1980) Response to fertilization by various plant growth forms in an Alaskan tundra: Nutrient accumulation and growth. Ecology 61:662-675

Sørensen LI, Mikola J, Kytöviita M-M (2008) Defoliation effects on plant and soil properties in an experimental low arctic grassland community-the role of plant community structure. Soil Biol Biochem 40:2596-2604

Srivastava DS, Jefferies RL (1995) Mosaics of vegetation and soil salinity: a consequence of goose foraging in an arctic salt marsh. Can J Bot 73:75-83

Srivastava DS, Jefferies RL (1996) A positive feedback: herbivory, plant growth, salinity, and the desertification of an Arctic salt-marsh. J Ecol 84:31-42

Treseder KK (2008) Nitrogen additions and microbial biomass: a meta-analysis of ecosystem studies. Ecol Lett 11:1111-1120 Weintraub MN, Schimel JP (2005a) The seasonal dynamics of amino acids and other nutrients in Alaskan Arctic tundra soils. Biogeochemistry 73:359-380

WeintraubMN, Schimel JP (2005b) Seasonal protein dynamics in Alaskan arctic tundra soils. Soil Biol Biochem37:1469-1475

Whipps JM (1990) Carbon economy. In: Lynch JM (ed) The rhizosphere. Wiley, New York, pp 52-97

Willis AJ (1963) Braunton Burrows: the effects on the vegetation of the addition of mineral nutrients to the dune soils. J Ecol 51:353-374

Wilson DJ, Jefferies RL (1996) Nitrogen mineralization, plant growth and goose herbivory in an Arctic coastal ecosystem. J Ecol 54:841-851

Wilson DJ, Van der Wal R, Chang E, Jensen A, Jefferies RL (1999) Urea hydrolysis and nitrification in saltmarsh soils: possible constraints on the growth of forage plants. Ecoscience 6:72-78

Witt C, Gaunt JL, Galicia CC, Ottow JCG, Neue HU (2000) A rapid chloroform-fumigation extraction method for measuring soil microbial biomass carbon and nitrogen in flooded rice soils. Biol Fert Soil 30:510-519 